\title{
Catch per unit effort (CPUE) periode lima tahunan perikanan pukat cincin di Kota Manado dan Kota Bitung
}

\author{
Catch per unit effort (CPUE) five-year period purse seine fishery in the city of Manado and \\ Bitung
}

\author{
Helmy A. Wurlianty*, Johny WenNo dan MARiana E. Kayadoe \\ Program Studi Pemanfaatan Sumberdaya Perikanan, Fakultas Perikanan dan Ilmu Kelautan, \\ Universitas Sam Ratulangi, Manado 95115
}

\begin{abstract}
Overfishing is due to increasing fishing capacity through increasing the size of fishing gears and vessels. This research aims to analyze the development of the five-year CPUE and maximum production of purse seine fishery in Manado and Bitung Cities periodically and determine changes in fishing capacity and its influence on CPUE. The results of this study are expected to provide information in the purse seine fishery management in the city of Manado and Bitung. The results of the analysis is the highest CPUE for Bitung occurred in the period 2005-2009, the lowest CPUE occurred in the period 2008-2012 and the highest CPUE for Manado occurred in the period 20082012, the lowest CPUE occurred in the period 2006-2010. The highest maximum production Bitung occurred in the period 2008-2012 amounted to 22.083 tons and maximum production of Manado occurred in the period 2006-2010 amounted to 7.855 tons. The number of vessels and their sizes in each five-year period there increased in line with the increase of production.
\end{abstract}

Keywords: catch, effort, purse seine, pelagic fish.

\begin{abstract}
ABSTRAK
Penangkapan ikan secara berlebihan terjadi karena meningkatnya kapasitas tangkap yaitu melalui penambahan ukuran alat tangkap dan ukuran kapal. Penelitian ini bertujuan untuk menganalisis perkembangan lima tahunan CPUE maupun produksi maksimum perikanan pukat cincin di Kota Manado dan Kota Bitung secara periodik dan mengetahui perubahan kapasitas tangkap dan pengaruhnya terhadap CPUE. Hasil penelitian ini diharapkan dapat memberikan informasi dalam pengelolaan perikanan pukat cincin di Kota Manado dan Kota Bitung. Hasil analisis yang diperoleh adalah CPUE tertinggi untuk Kota Bitung terjadi pada periode tahun 2005-2009, CPUE terendah terjadi pada periode tahun 2008-2012 dan CPUE tertinggi untuk Kota Manado terjadi pada periode tahun 20082012, CPUE terendahnya terjadi pada periode tahun 2006-2010. Produksi maksimum tertinggi Kota Bitung terjadi pada periode tahun 2008-2012 sebesar 22.083 ton dan produksi maksimum Kota Manado terjadi pada periode tahun 2006-2010 sebesar 7.855 ton. Jumlah kapal dan ukuran kapal pada setiap periode lima tahunan meningkat seiring dengan peningkatan produksi.
\end{abstract}

Kata-kata kunci: hasil tangkapan, upaya, pukat cincin, ikan pelagis

\section{PENDAHULUAN}

Stock atau ketersediaan ikan di berbagai wilayah perairan Indonesia telah mengalami tangkap berlebihan (overfishing). Produktivitas mengalami penurunan, ikan yang tertangkap semakin kecil, dan daerah penangkapan yang menjadi pusat operasi penangkapan memiliki jarak yang semakin

\footnotetext{
*Penulis untuk penyuratan; email: hamsdynov@gmail.com
}

jauh dari pantai (Zulbainarni, 2012). Penurunan produktivitas sumberdaya dan terjadinya penangkapan secara berlebihan pada suatu wilayah perairan disebabkan oleh perubahan kapasitas tangkap yaitu penambahan jumlah serta ukuran alat tangkap dan kapal. Perubahan kapasitas tangkap ini mengakibatkan ketersediaan sumberdaya ikan pada suatu perairan akan habis ditangkap pada upaya penangkapan yang lebih 
sedikit (Cunningham et al., 1985). Bila penangkapan ikan ini dilakukan terus menerus dikuatirkan populasinya cenderung berkurang karena siklus hidupnya dapat terganggu bila tanpa diikuti dengan pertumbuhan dan reproduksi; bahkan tidak ada lagi habitat yang kondusif untuk melepaskan telur. Kalau populasi cenderung berkurang bahkan sampai tidak ada sama sekali, maka akan berdampak pula pada perekonomian masyarakat nelayan (Kawimbang dkk, 2012). Sehubungan dengan itu, maka perlu adanya penanganan secara terkontrol terhadap penangkapan yang berlebihan. Penelitian ini bertujuan untuk menganalisis perkembangan lima tahunan catch per unit effort (CPUE) maupun produksi maksimum perikanan pukat cincin dan mengetahui perubahan kapasitas tangkap perikanan pukat cincin di Kota Manado dan Kota Bitung serta pengaruhnya terhadap CPUE secara periodik.

\section{METODE PENELITIAN}

\section{Metode pengumpulan data}

Metode penelitian yang digunakan yaitu metode survei (Nazir, 1985 dalam Kawimbang dkk, 2012). Data yang dipakai untuk metode ini adalah data sekunder yang diperoleh dari PPS Bitung dan PPP Tumumpa, Manado.

\section{Analisis data}

Analisis data yang digunakan adalah CPUE dengan mengikuti petunjuk Schaefer (1957) yang dikemukakan oleh Gulland (1983) dengan rumus:

$$
q=\frac{h}{f}
$$

di mana:

$q=$ CPUE (kg/trip)

$h=$ Catch atau hasil tangkapan $(\mathrm{kg})$

$f=$ Effort atau upaya penangkapan (trip).

Berdasarkan nilai CPUE dari hasil tangkapan (h) dapat digunakan untuk pendugaan tangkapan maksimum secara sederhana. Menurut Schaefer (1957) dalam Fauzi (2006), model untuk menentukan tangkapan maksimum tersebut antara lain ditentukan oleh:

a) Hubungan antara upaya penangkapan ( $f$ ) dengan CPUE $(q)$ mempunyai hubungan linier sehingga dapat ditulis dalam bentuk persamaan linier yaitu:

$$
q=a-b f
$$

b) Hubungan antara hasil tangkapan $(h)$ dengan upaya penangkapan $(f)$ mempunyai hubungan kuadratik yang dapat ditulis dalam bentuk persamaan kuadratik yaitu:

$$
h=a f-b f^{2}
$$

c) Berdasarkan dua persamaan di atas maka upaya optimum dapat dihitung dengan cara menyamakan persamaan (3) sama dengan nol, sehingga dapat ditulis dalam bentuk rumus yaitu:

$$
f=\frac{a}{2 b}
$$

d) Hasil tangkapan maksimum dapat diperoleh dengan mensubstitusikan nilai upaya optimum ke dalam persamaan (3), sehingga diperoleh:

$$
\text { Produksi Max }=\frac{a^{2}}{4 b}
$$

\section{HASIL DAN PEMBAHASAN}

\section{Hasil Penelitian}

Hasil tangkapan dan upaya penangkapan menjadi fokus dalam penelitian ini, yaitu hubungan antara hasil tangkapan dan upaya penangkapan, sehingga dapat dihitung CPUE periode lima tahunan. Hasil tangkapan, upaya penangkapan, dan CPUE produksi ikan pelagis dapat dilihat pada Tabel 1 .

Data yang diperoleh sejak tahun 2004-2012 di PPS Bitung dikelompokkan ke dalam kelompok lima tahunan. Data periode lima tahunan dilakukan untuk menduga populasi ikan dan menghitung maximum sustainable yield. Setiap periode lima tahunan dihitung fungsi CPUE (hubungan upaya dan CPUE), kurva fungsi produksi (dalam bentuk kurva kuadratik) untuk memperoleh puncak tangkapan. Hubungan CPUE dengan upaya untuk periode tahun 2004-2008 mengikuti persamaan $\mathrm{Y}=$ 2126-0,0677X; periode tahun 2005-2009 mengikuti persamaan $\mathrm{Y}=2143-0,0618 \mathrm{X}$; periode tahun 2006-2010 mengikuti persamaan $\mathrm{Y}=2137$ 0,0599X; periode tahun 2007-2011 mengikuti persamaan $\mathrm{Y}=1678-0,0364 \mathrm{X}$; dan periode tahun 2008-2012 mengikuti persamaan $\mathrm{Y}=1532$ 0,0252X. Persamaan-persamaan tersebut ditransfer ke dalam bentuk grafik seperti pada Gbr. 1. 
Tabel 1. Produksi, upaya penangkapan, dan CPUE di PPS Bitung.

\begin{tabular}{cccc}
\hline Tahun & Produksi $(\mathrm{kg})$ & Upaya (trip) & CPUE $(\mathrm{kg} /$ trip) \\
\hline 2004 & 12.613 .020 & 10.573 & $1.192,95$ \\
2005 & 15.084 .025 & 10.213 & $1.476,94$ \\
2006 & 16.625 .357 & 10.090 & $1.647,71$ \\
2007 & 15.760 .994 & 20.928 & 753,11 \\
2008 & 16.563 .557 & 16.456 & $1.006,54$ \\
2009 & 18.410 .067 & 24.634 & 747,34 \\
2010 & 18.173 .243 & 24.634 & 737,73 \\
2011 & 25.749 .338 & 20.824 & $1.236,52$ \\
2012 & 27.813 .334 & 24.472 & $1.136,54$ \\
\hline
\end{tabular}

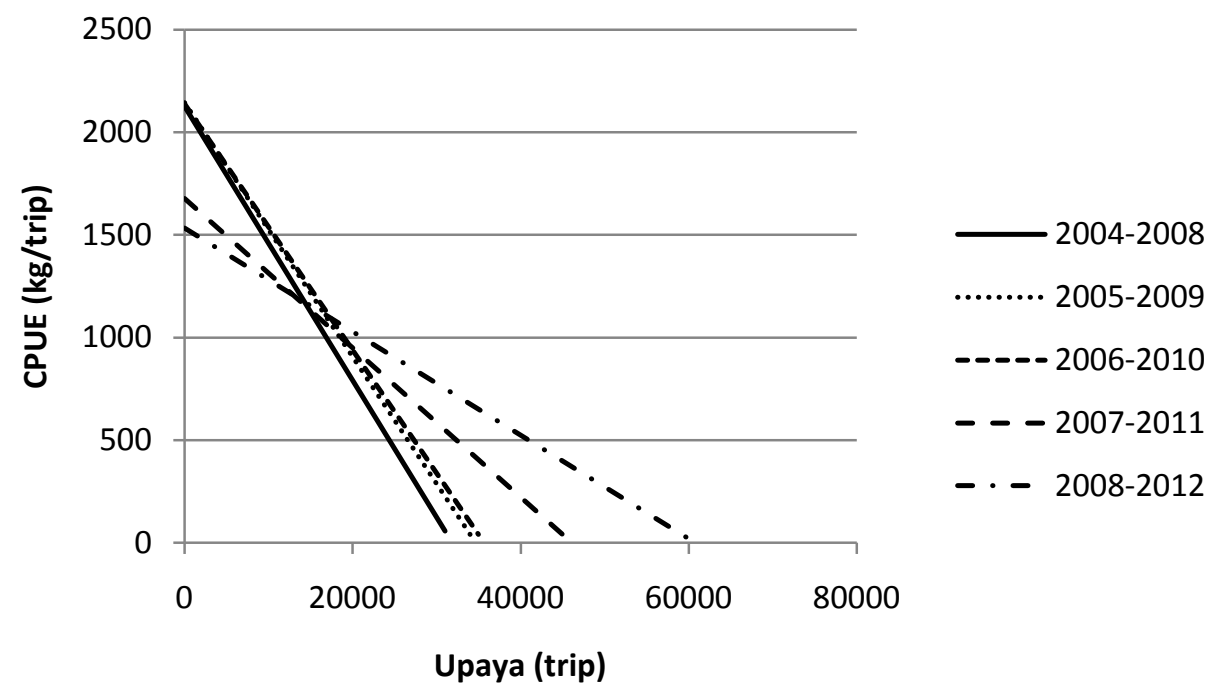

Gambar 1. CPUE di PPS Bitung

Melalui persamaan serta grafik tersebut dapat diketahui bahwa grafik dengan nilai intersept $a$ yang rendah menunjukkan bahwa kapasitas tangkap per unit upaya lebih rendah dan grafik dengan nilai $a$ yang lebih tinggi menunjukkan kapasitas tangkap per unit upaya lebih tinggi. Jadi periode tahun 2008-2012 tingkat upaya yang beroperasi mempunyai kapasitas tangkap rata-rata lebih rendah dibanding periode tahun lainnya. Kapasitas tangkap yang tinggi terjadi pada tahun 2005-2009.

Hasil analisis hubungan antara produksi dengan upaya menghasilkan persamaan-persamaan pada periode lima tahunan seperti pada Tabel 2. Tabel 2 dapat ditransfer ke dalam bentuk grafik kuadratik atau parabola seperti pada Gbr. 2.
Gambar 2 memperlihatkan bahwa produksi maksimum paling rendah terjadi pada periode tahun 2004-2008. Periode tahun 2005-2009 produksi maksimum meningkat dibandingkan periode sebelumnya pada tingkat upaya lebih tinggi. Periode tahun 2006-2010 puncak produksi lebih tinggi dari periode sebelumnya yang dapat dicapai pada upaya yang lebih tinggi. Periode 2007-2011, puncak produksi terus meningkat dibandingkan dengan periode sebelumnya dan tingkat upaya pun terus meningkat dibandingkan dengan periode sebelumnya. Periode 2008-2012 memiliki puncak produksi atau produksi maksimum yang paling tinggi dan upaya yang dicapai lebih tinggi dari periode sebelumnya. 
Tabel 2. Hasil analisis hubungan produksi dengan upaya penangkapan di PPS Bitung

\begin{tabular}{cccc}
\hline Periode Tahun & Persamaan & Foptimum (trip) & Produksi Max (kg) \\
\hline $2004-2008$ & $\mathrm{Y}=2090 \mathrm{X}-0,0644 \mathrm{X}^{2}$ & 16.227 & 16.956 .910 \\
$2005-2009$ & $\mathrm{Y}=1966 \mathrm{X}-0,0527 \mathrm{X}^{2}$ & 18.653 & 18.335 .655 \\
$2006-2010$ & $\mathrm{Y}=1867 \mathrm{X}-0,0473 \mathrm{X}^{2}$ & 19.736 & 18.423 .303 \\
$2007-2011$ & $\mathrm{Y}=1804 \mathrm{X}-0,0421 \mathrm{X}^{2}$ & 21.425 & 19.325 .511 \\
$2008-2012$ & $\mathrm{Y}=1733 \mathrm{X}-0,0340 \mathrm{X}^{2}$ & 25.485 & 22.083 .007 \\
\hline
\end{tabular}

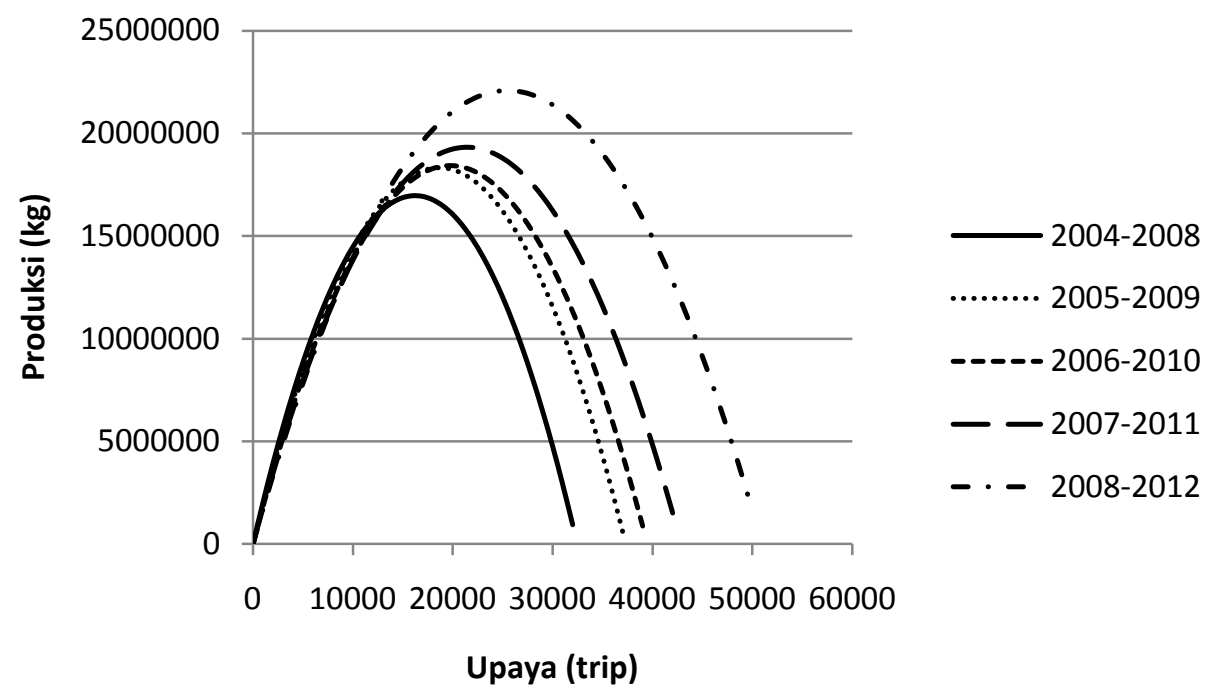

Gambar 2.Kurva produksi di PPS Bitung.

Tabel 1 memberikan petunjuk bahwa selama periode 2004-2008, terjadi penurunan CPUE yang cukup menyolok pada tahun 2007 dibanding tahun 2006. Produksi maksimum yang diperoleh secara riil yaitu pada tahun 2006 sebesar $16.625 .357 \mathrm{~kg}$. Hasil maksimum yang dapat dicapai pada periode 2004-2008 berdasarkan model persamaan kuadratik yaitu sebesar $16.956 .910 \mathrm{~kg}$. Hal ini berarti bahwa produksi maksimum pada tahun 2006 telah mendekati puncak maksimum lestari sumberdaya ikan di daerah penangkapan di mana hasil tangkapan diperoleh. Karena itu perlu ada peningkatan kapasitas armada untuk ekspansi ke daerah penangkapan yang lebih luas atau lebih jauh.

Penurunan nilai CPUE juga terjadi pada tahun 2009, 2010, 2012, sedangkan terjadi kenaikan pada tahun 2008 dan tahun 2011. Periode 20052009, produksi maksimum lestari sebesar $18.335 .655 \mathrm{~kg}$ berada di bawah produksi sebenarnya yang tertinggi yaitu pada tahun 2009 sebesar 18.410.067 kg. Periode 2006-2010 produksi maksimum lestari sebesar 18.423.3003 kg lebih tinggi dari poduksi riil pada tahun 2009 sebesar 18.410.067 kg. Periode 2007-2011 produksi maksimum lestari lebih rendah dari produksi riil tahun 2011 sebesar $25.749 .338 \mathrm{~kg}$. Periode 2008-2012 produksi maksimum lestari lebih rendah dari produksi riil tertinggi tahun 2012 sebesar $27.813 .314 \mathrm{~kg}$.

Keadaan tersebut di atas menunjukkan bahwa sumberdaya ikan pelagis di daerah penangkapan kapal-kapal pukat cincin yang mendaratkan ikan di PPS Bitung telah menunjukkan gejala yang sangat memprihatinkan atau dapat dikatakan telah terjadi overfishing karena produksi riil lebih tinggi dari produksi maksimum yang seharusnya dicapai agar sumberdaya dalam keadaaan lestari. Ini perlu mendapat perhatian untuk pengelolaan sumberdaya ikan pelagis secara lebih bijaksana di daerah 
penangkapan yang ada serta disarankan untuk mencari daerah penangkapan potensial yang baru sehingga sumberdaya tidak terancam punah.
Hubungan produksi dengan upaya dari produksi ikan pelagis yang di daratkan di PPP Tumumpa periode lima tahunan dihitung berdasarkan data pada Tabel 3.

Tabel 3. Produksi, upaya penangkapan, dan CPUE di PPP Tumumpa.

\begin{tabular}{cccc}
\hline Tahun & Produksi $(\mathrm{kg})$ & Upaya (trip) & CPUE (kg/trip) \\
\hline 2004 & 4.130 .310 & 8.247 & 500,8 \\
2005 & 5.178 .200 & 8.039 & 644,1 \\
2006 & 4.459 .900 & 7.954 & 560,7 \\
2007 & 4.921 .900 & 15.095 & 326,1 \\
2008 & 6.298 .900 & 10.954 & 575,0 \\
2009 & 7.036 .600 & 19.552 & 359,9 \\
2010 & 7.057 .200 & 19.552 & 360,9 \\
2011 & 8.714 .900 & 11.457 & 760,7 \\
2012 & 7.535 .600 & 15.254 & 494,0 \\
\hline
\end{tabular}

Data yang diperoleh sejak tahun 2004-2012 di PPP Tumumpa dikelompokkan ke dalam kelompok lima tahunan. Setiap periode lima tahunan dihitung fungsi CPUE (hubungan upaya dan CPUE), kurva fungsi produksi (dalam bentuk kurva kuadratik) untuk memperoleh puncak tangkapan tertinggi pada upaya optimum.

Hubungan CPUE dengan upaya untuk periode tahun 2004-2008 mengikuti persamaan $\mathrm{Y}=847$ -
0,324X; periode tahun 2005-2009 mengikuti persamaan $\mathrm{Y}=801-0,0250 \mathrm{X}$; periode tahun 20062010 mengikuti persamaan $\mathrm{Y}=729-0,200 \mathrm{X}$; periode tahun 2007-2011 mengikuti persamaan $\mathrm{Y}=1020-0,0355 \mathrm{X}$; periode tahun 2008-2012 megikuti persamaan $\mathrm{Y}=1064-0,0361 \mathrm{X}$. Persamaan-persamaan tersebut dapat ditransfer ke dalam bentuk grafik seperti pada Gbr. 3 .

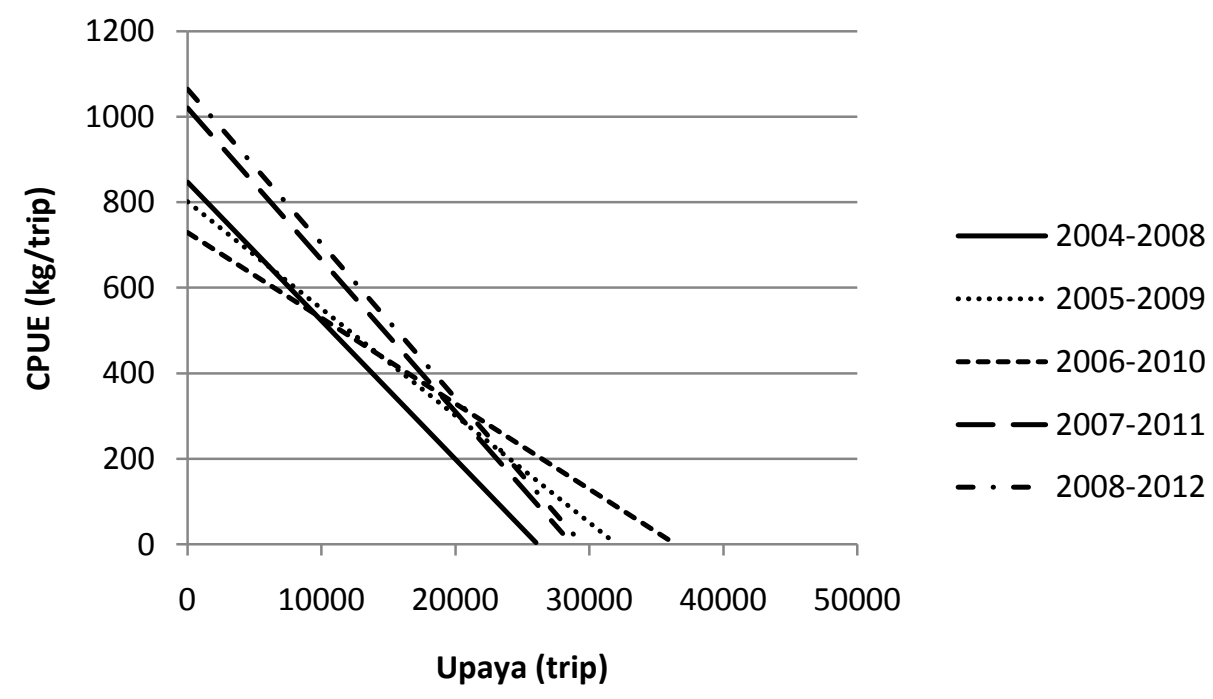

Gambar 3. Grafik CPUEdi PPP Tumumpa 
Melalui persamaan serta grafik tersebut dapat diketahui bahwa grafik dengan nilai $a$ yang rendah menunjukkan bahwa kapasitas tangkap per unit upaya lebih rendah dari grafik dengan nilai $a$ yang lebih tinggi menunjukkan kapasitas tangkap per unit upaya lebih tinggi. Jadi periode tahun 20062010 tingkat upaya yang beroperasi mempunyai kapasitas tangkap rata-rata lebih rendah dibanding periode tahun lainnya. Kapasitas tangkap yang tinggi terjadi pada periode tahun 2008-2012.

Hasil analisis hubungan antara produksi dengan upaya menghasilkan persamaan-persamaan pada periode lima tahun seperti pada Tabel 4.

Berdasarkan Tabel 4 maka persamaan atau fungsi produksi dapat ditransfer ke dalam bentuk grafik seperti pada Gbr 4.

Tabel 4. Hasil analisis hubungan produksi dengan upaya penangkapan di PPP Tumumpa

\begin{tabular}{cccc}
\hline Periode Tahun & Persamaan & Foptimum (trip) & Produksi Max $(\mathrm{kg})$ \\
\hline $2004-2008$ & $\mathrm{Y}=891 \mathrm{X}-0,0363 \mathrm{X}^{2}$ & 12.274 & 5.467 .500 \\
$2005-2009$ & $\mathrm{Y}=750 \mathrm{X}-0,0215 \mathrm{X}^{2}$ & 19.971 & 6.780 .015 \\
$2006-2010$ & $\mathrm{Y}=679 \mathrm{X}-0,0170 \mathrm{X}^{2}$ & 14.751 & 7.854 .744 \\
$2007-2011$ & $\mathrm{Y}=939 \mathrm{X}-0,0306 \mathrm{X}^{2}$ & 17.442 & 6.540 .698 \\
$2008-2012$ & $\mathrm{Y}=1061 \mathrm{X}-0,0361 \mathrm{X}^{2}$ & 15.343 & 7.203 .603 \\
\hline
\end{tabular}

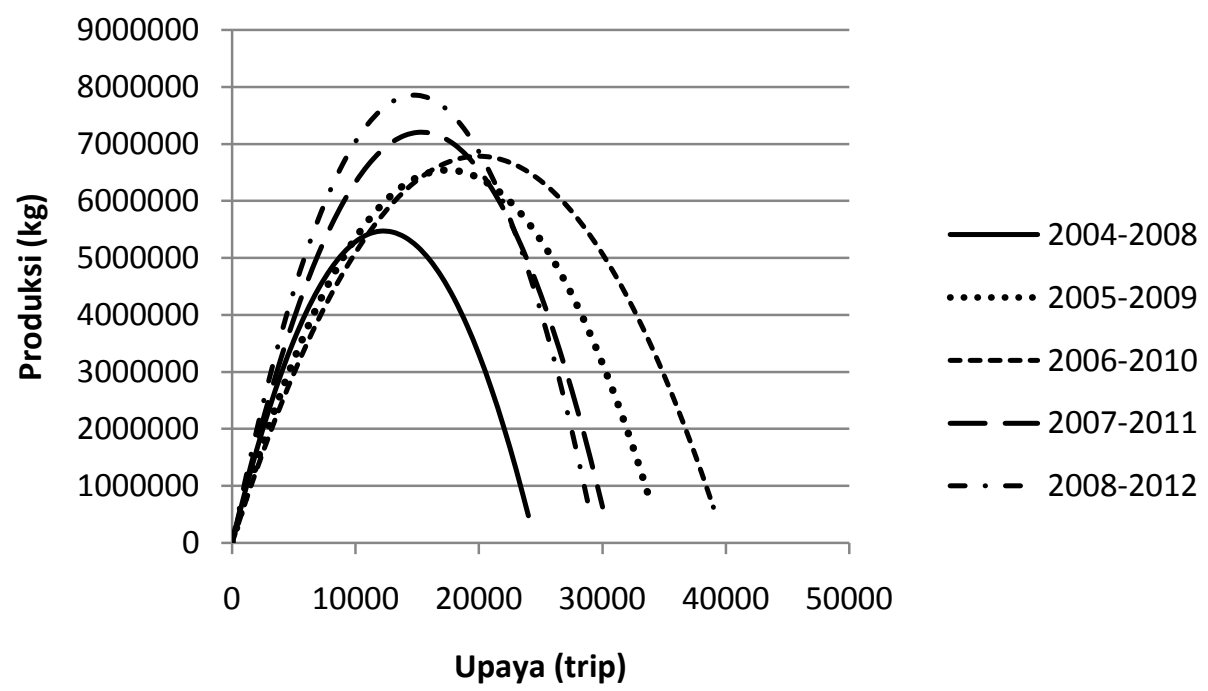

Gambar 4. Kurva produksi di PPP Tumumpa

Dari Tabel 4 dan Gbr. 4 terlihat bahwa dengan terjadi perubahan kapasitas tangkap yang meningkat pada setiap periode lima tahunan, maka puncak produksi dicapai pada tingkat upaya yang rendah. Semakin meningkat kapasitas tangkap maka produksi semakin meningkat namun produksi maksimum dicapai pada tingkat upaya yang lebih rendah.

Gambar 4 memperlihatkan bahwa produksi maksimum yang paling rendah terjadi pada periode tahun 2004-2008. Periode tahun 2005-
2009 produksi maksimum meningkat dibanding periode sebelumnya pada tingkat upaya yang lebih tinggi. Periode tahun 2006-2010 puncak produksi lebih tinggi dari periode sebelumnya yang dapat dicapai pada tingkat upaya yang lebih tinggi. Periode tahun 2007-2011, puncak produksi terus naik namum puncak produksi yang dicapai pada tingkat upaya yang lebih rendah dari periode sebelumnya. Periode tahun 2008-2012 puncak produksi adalah yang paling tinggi yang dapat dicapai pada tingkat upaya yang lebih rendah dari 
periode tahun sebelumnya. Dengan demikian dapat disimpulkan bahwa jika terjadi perubahan kapasitas tangkap kearah yang lebih tinggi, maka produksi yang dihasilkan akan lebih tinggi, namun puncak produksi atau produksi maksimum akan dicapai pada tingkat upaya yang lebih rendah. Hal ini jika tidak diperhatikan akan menguras sumberdaya dengan cepat dan akan mengancam ketersediaan sumberdaya.

Tabel 3 memberikan petunjuk bahwa selama periode 2004-2008, terjadi penurunan CPUE yang cukup menyolok pada tahun 2007 dibanding tahun 2006. Produksi maksimum tertinggi yang diperoleh secara riil yaitu pada tahun 2008 sebesar $6.298 .900 \mathrm{~kg}$. Hasil maksimum yang dapat dicapai pada periode tahun 2004-2008 berdasarkan model persamaan kuadratik yaitu sebesar $5.467 .500 \mathrm{~kg}$. Hal ini berarti bahwa produksi maksimum pada tahun 2008 telah melewati puncak maksimum lestari sumberdaya ikan di daerah penangkapan di manan hasil tangkapan diperoleh. Oleh sebab itu, perubahan kapasitas tangkap dan penambahan upaya penangkapan harus segera dikontrol, karena akan membahayakan sumberdaya ikan pelagis yang ada di daerah penangkapan yang dilakukan operasi penangkapan.

Penurunan nilai CPUE juga terjadi pada tahun 2009, 2010, dan 2012, sedangkan terjadi kenaikan pada tahun 2008 dan tahun 2011. Periode 20052009, produksi maksimum lestari sebesar $6.780 .015 \mathrm{~kg}$ berada di bawah produksi sebenarnya yang tertinggi yaitu pada tahun 2009 sebesar $7.036 .600 \mathrm{~kg}$. Periode 2006-2010 produksi maksimum lestari sebesar $7.854 .744 \mathrm{~kg}$ lebih tinggi dari produksi riil tertinggi pada tahun 2010 sebesar 7.057.200 kg. Periode tahun 2007-2011 produksi maksimum lestari lebih rendah dari produksi riil tertinggi tahun 2011 sebesar $8.714 .900 \mathrm{~kg}$. Periode 2008-2012 produksi maksimum lestari lebih rendah dari produksi riil tertinggi tahun 2011 sebesar $8.714 .900 \mathrm{~kg}$.

Keadaan tersebut di atas menunjukkan bahwa sumberdaya ikan pelagis di daerah penangkapan kapal-kapal pukat cincin yang mendaratkan ikan di PPP Tumumpa telah menunjukkan gejala yang sangat memprihatinkan atau dapat dikatakan telah terjadi overfishing. Ini perlu mendapat perhatian untuk pengelolaan sumberdaya ikan pelagis secara lebih bijaksana di daerah penangkapan yang ada serta disarankan untuk mencari daerah penangkapan potensial yang baru sehingga sumberdaya tidak terancam punah.

Perubahan kapasitas tangkap diukur berdasarkan perubahan jumlah armada penangkapan pukat cincin periode tahun 2004-2012 yang dapat dilihat pada Tabel 5 untuk pukat cincin yang di daratkan di PPS Bitung dan Tabel 6 untuk pukat cincin yang di daratkan di PPP Tumumpa. Tabel 5 memperlihatkan bahwa perkembangan jumlah kapal dan ukuran kapal periode lima tahunan memiliki peningkatan, di mana peningkatan tersebut membawa dampak bagi perubahan produksi yang didaratkan di PPS Bitung.

Tabel 6 memperlihatkan bahwa perkembangan jumlah kapal dan ukuran kapal terlebih ukuran kapal 20-30 GT yang penangkapannya cukup menonjol membuktikan bahwa ada upaya nelayan untuk menjangkau daerah penangkapan yang lebih jauh. Peningkatan ini juga memberi pengaruh terhadap peningkatan produksi dan perubahan CPUE.

Tabel 5. Jumlah Kapal dan Ukuran Kapal di PPS Bitung

\begin{tabular}{ccccc}
\hline \multirow{2}{*}{ Tahun } & \multicolumn{5}{c}{ GT } \\
\cline { 2 - 5 } & $5-10$ & $10-20$ & $20-30$ & $30-50$ \\
\hline 2004 & 4 & 8 & 18 & 10 \\
2005 & 4 & 8 & 18 & 11 \\
2006 & 4 & 8 & 36 & 12 \\
2007 & 5 & 9 & 18 & 12 \\
2008 & 5 & 8 & 36 & 13 \\
2009 & 4 & 9 & 18 & 16 \\
2010 & 4 & 9 & 18 & 10 \\
2011 & 10 & 15 & 56 & 15 \\
2012 & 10 & 15 & 65 & 17 \\
\hline
\end{tabular}


H.A. Wurlianty dkk.

Tabel 6. Jumlah kapal dan ukuran kapal di PPP Tumumpa

\begin{tabular}{cccccccc}
\hline \multirow{2}{*}{ Tahun } & \multicolumn{7}{c}{ GT } \\
\cline { 2 - 7 } & $5-10$ & $10-20$ & $20-30$ & $30-50$ & $50-100$ & $100-200$ & $200-300$ \\
\hline 2004 & 25 & 30 & 30 & 35 & 35 & 35 & 35 \\
2005 & 27 & 27 & 32 & 35 & 32 & 33 & 32 \\
2006 & 25 & 27 & 34 & 32 & 30 & 30 & 30 \\
2007 & 25 & 27 & 35 & 29 & 27 & 28 & 29 \\
2008 & 28 & 30 & 32 & 35 & 30 & 34 & 34 \\
2009 & 29 & 32 & 30 & 36 & 35 & 35 & 35 \\
2010 & 29 & 32 & 30 & 36 & 35 & 35 & 35 \\
2011 & 28 & 30 & 38 & 34 & 32 & 31 & 32 \\
2012 & 30 & 37 & 32 & 37 & 36 & 35 & 38 \\
\hline
\end{tabular}

\section{Pembahasan}

Menurunnya CPUE pada periode tahun tertentu disebabkan oleh semakin jauhnya daerah penangkapan serta akibat pengaruh perubahan kondisi alam/lingkungan (cuaca, angin, salinitas, musim) terhadap populasi dan komunitas sumberdaya, di mana untuk faktor lingkungan ini diperoleh dari penelitian tersendiri yang meneliti tentang hal tersebut.

Upaya penangkapan atau effort apabila terus dilakukan penambahan, maka akan berpengaruh terhadap produktivitas sumberdaya perikanan yang akan mengalami penurunan yang sangat signifikan. Hal ini apabila dibiarkan maka akan membahayakan sumberdaya perikanan yang ada di Kota Manado dan Kota Bitung dan yang terjadi adalah pengurasan sumberdaya dengan cepat.

Penangkapan berlebihan harus segera diperhatikan dengan cara pengelolaan sumberdaya seperti pengaturan upaya penangkapan, pengaturan ukuran mata jaring dan penutupan musim atau daerah penangkapan (Widodo dan Suadi, 2006 dalam Syakila, 2009). Namun demikian dalam pengelolaan perikanan sangat sulit untuk mengatur dan merubah kondisi yang telah ada sehingga upaya yang mungkin dilakukan adalah hanya berupa pembatasan seperti tidak mengizinkan perahu penangkap baru yang akan masuk ke perairan serta membatasi jumlah tangkapan nelayan tanpa mengurangi jumlah perahu nelayan yang telah ada saat ini sehingga tercapai pemanfaatan yang optimum.

\section{KESIMPULAN}

Berdasarkan hasil analisis yang telah dilakukan maka dapat ditarik beberapa kesimpulan yaitu:
Perkembangan CPUE dan produksi maksimum di Kota Manado dan Kota Bitung menunjukkan bahwa sumberdaya ikan pelagis di daerah penangkapan kapal-kapal pukat cincin yang mendaratkan ikan di PPS Bitung dan PPP Tumumpa telah menunjukkan gejala yang sangat memprihatinkan atau dapat dikatakan telah terjadi overfishing. Ini perlu mendapat perhatian untuk pengelolaan sumberdaya ikan pelagis secara lebih bijaksana di daerah penangkapan yang ada serta disarankan untuk mencari daerah penangkapan potensial yang baru, sehingga sumberdaya tidak terancam punah.

Perubahan kapasitas tangkap setiap periode lima tahunan yang terjadi di Kota Manado dan Kota Bitung mengalami peningkatan dari jumlah kapalnya atau pun perubahan ukuran kapal itu sendiri.

\section{DAFTAR PUSTAKA}

Cunningham, S., M.R Dunn, and D. Whitmarsh. 1985. Fisheries Economics: An Introduction. Mansell Publishing Limited Edition. St. Marthin's Press, New York.

Fauzi, A. 2006. Ekonomi Sumberdaya Alam dan Lingkungan Teori dan Praktek. PT. Gramedia Pustaka Utama, Jakarta.

Gulland, J.A. 1983. Fish Stock Assement: A Manual of Basic Method. John Wiley and Sons. Inc, NewYork.

Kawimbang E., I.J. Paransa, dan M.E. Kayadoe. 2012. Pendugaan stok dan musim penangkapan ikan julungjulung dengan soma roa di Perairan Tagulandang, Kabupaten Kepulauan Siau Tagulandang Biaro. Jurnal Ilmu dan Teknologi Perikanan Tangkap 1(1): 10-17.

Syakila, S. 2009. Studi dinamika stok ikan tembang (Sardinella fimbriata) di perairan Teluk Pelabuhan Ratu, Kabupaten Sukabumi, Provinsi Jawa Barat. Skripsi. Manajemen Sumberdaya Perikanan. Institut Pertanian Bogor.

Zulbainarni, N. 2012. Teori dan Praktik Pemodelan Bioekonomi dalam Pengelolaan Perikanan Tangkap. IPB Press. 